\title{
感情予測がテスト勉強の動機づけに及ぼす影響
}

\author{
社会心理学の試験を用いた検討 \\ $\bigcirc$ 村田光二 1 \\ ( 1 一橋大学大学院社会学研究科) \\ キーワード : 感情予測、達成動機づけ
}

\section{Effect of affective forecasting on achievement motivation in a college class \\ Koji Murata $^{1}$ \\ ( ${ }^{1}$ Graduate School of Social sciences, Hitotsubashi University)}

Key Words: affective forecasting, achievement motivation

\section{目 的}

私たちは将来の出来事について思いをめぐらすことがある。 それが望ましい結果になったときのポジティブ感情を予測し たり、逆に望まない結果が生じたときのネガティブ感情を予 測することもある。これら感情反応の予測は実際よりも強く なりやすいことが指摘され、インパクトバイアスと呼ばれて いる（Wilson \& Gilbert, 2003)。こういった感情反応の行き 過ぎた予測は、その出来事を成功させるよう、あるいは失敗 を回避できるよう、私たちを動機づける可能性を指摘できる だろう（村田，2010）。本研究では、大学の授業を利用して、 その試験結果についいての感情反応を想像させることによっ て、その時点での試験勉強に対する動機づけを高めることが できるかどうかを検討した。試験の約 1 週間前に試験終了後 を考えさせて、単に起きうる出来事を想像させた学生と比べ て、ポジティブな結果を想像させた学生も、ネガティブな結 果を想像させた学生も、試験勉強に対する意欲が高まると仮 説を立てた。なお、試験の後にも調查を実施して、実際の試 験勉強等についても回答を求めた。

\section{方 法}

【参加者】東京大学教養学部で著者が担当している「社会行 動論」を受講している学生のうち 101 名（女性 20 名）が 20 名程度の集団単位で実験に参加した。

【手続き】実験は 2013 年の 1 月下旬に教室で実施され、ラン ダムに配布された 3 通り（条件）の質問紙の 1 つを読んで回 答した。質問紙の表紙には「学業課題に関する推論研究 1 」 と書かれていて、将来試験の時に起こるかもしれない仮想場 面を思い浮かべてもらい、その場面の自分の状態について推 論すると説明を受けた。次に、2ページにある試験の難易度 や重要性に関する事前の質問に回答した。そして、一斉に 3 ページ目を開けてもらい、試験が終わったときのことを想像 してもらった。ポジティブ（P）条件では、「予想以上に試験 が良くできて、楽しいことや嬉しいことを考えている」とし たらどんな内容なのか、その場面について思いつくことを最 大 8 項目記述してもらった。ネガティブ $(\mathrm{N})$ 条件では、「予 想より試験のできが悪くて、嫌なことや悔しいことを考えて いる」場面について思いつくことを記述してもらった。統制 条件では特に場面を限定せずに、駅に向かって歩いていると きに考えていることを記述してもらった。この作業をいずれ の条件でも 6 分間で実施させ、合図によって終了した。 4 ペ ージに進んで想像内容のチェック項目、試験勉強に費や寸時 間の予測、試験のための努力の程度、他の試験やレポートの 数、成績の予想などについて回答を求めた。

質問紙への回答が終了した後に、試験後に実施してもらう 事後調查と郵送による提出の仕方について説明した。研究内 容の説明については、事後調査を提出した者に対して、基本 的な分析結果を含んだ説明文書をメールに添付して（あるい は郵便で）送ることによって行った。こういった事後調查を
含んだ手続き全体については、実験開始前に説明して、了解 を得た上で参加してもらった。

結 果

【分析対象者と操作チェック】事後調査を期日以内に郵送し た 92 名を分析対象とした。想像した内容の好ましさをたずね ると、平均值は表 1 の 1 行目のようになった。条件間で予測 通りの有意差があり $(F(2,89)=32.6 p<.001)$ 、操作は成功した と考えられた。

\begin{tabular}{|c|c|c|c|c|}
\hline & $\mathrm{P}(29)$ & $\mathrm{N}(29)$ & 統制 (34) & （範囲） \\
\hline 想像の好ましさ & 7.69 & 2.86 & 5.35 & $0-10$ \\
\hline 勉強時間予測 & 9.86 & 8.91 & 8.65 & $0^{-}(\mathrm{h})$ \\
\hline 努力量の予測 & 5.17 & 5.45 & 5.24 & $1-7$ \\
\hline 勉強時間報告 & 6.24 & 7. 52 & 6.47 & $0^{-} \quad(h)$ \\
\hline 努力量報告 & 3.90 & 4. 24 & 4. 15 & $1-7$ \\
\hline
\end{tabular}

【直後の動機づけ】約 1 週間後の試験のために費やす時間を たずねた質問の結果は表 1 の 2 行目に示したとおりである。 この平均值については、条件間でほとんど差が認められなか った。この指標には大きい值（最大值 25 時間）を答える者も

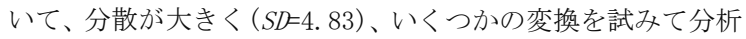
したが、いずれの場合にも意味のある結果は得られなかった。 また、努力量の予測の回答にも条件間の差は認められなかっ た。このように、主たる仮説は支持されなかった。

【実際のテスト勉強】事後調査では、実際の勉強時間と努力 量の事後評価を報告させた。この指標にも条件間に有意な差 は認められなかったが、全体として、勉強時間は予測よりも 短く $(t(91)=4.70 \quad p<.001)$ 、努力量は予測よりも少なかった $(t(91)=8.18 p<.001)$ 。このうに、今回測定した動機づけの 指標では、予測したほど実際には課題遂行への努力をしなか ったという計画錯詋が認められた。

\section{考 察}

感情予測が動機づけに影響を及ぼす証拠を得られなかった 理由として、いくつかの可能性が考えられる。まず、この実 験状況での勉強時間や努力量の予測は自己呈示としての意味 が強く、望ましい方向に回答するバイアスが参加者全員に働 いていた可能性がある。また、意識的過程を経る自己報告の 指標ではなく、行動指標など非意識的な測定方法を工夫する 必要があったかもしれない。さらに、影響が認められるため には自発的な感情予測が必要かもしれないし、それが繰り返 される必要があった可能性もある。制御焦点の個人差（P予 測は促進焦点、N予測は予防焦点）など、影響を調整する要 因を組み込む必要もあるかもしれない。

\section{引用文献}

村田光二 2010 感情予測 村田(編)『社会と感情』北大路書 房 pp. 121-146. Wilson, T. D. \& Gilbert, D. T. 2003 Affective forecasting in Adv. Exp. Soc. Psychol., 35, 345-411. 